\title{
KATALOG SKRIPSI ONLINE PADA PROGRAM STUDI TEKNIK INFORMATIKA
}

\author{
Ahmad Jazuli \\ Fakultas Teknik, Program Studi Teknik Informatika \\ Universitas Muria Kudus \\ Email: ahmad.jazuli@umk.ac.id \\ Mukhamad Nurkamid \\ Fakultas Teknik, Program Studi Teknik Informatika \\ Universitas Muria Kudus \\ Email: muhammad.nurkamid@umk.ac.id
}

\begin{abstract}
ABSTRAK
Program Studi Teknik Informatika didalam pengelolaan skripsi dari awal program studi berdiri tahun 2009 masih dilakukan secara manual. Proses pengelolaan manual ini dokumen kelengkapan dan berkas skripsi di catat dan di dokumentasikan dengan menggunakan format file microsoft excel. Kelemahan pengelolaan menggunakan dokumen spreatsheet cukup banyak, selain dokumen sulit di cari keberadaannya dan dokumen dapat tersebar di beberapa file, selain itu kebutuhan data dan informasi yang lengkap terkait hasil penjadwalan ujian, pembimbingan skripsi dan seminar hasil sulit teridentifikasi dan terkelola dengan baik. Penelitian ini membuat katalog pengelolaan skripsi pada program studi Teknik Informatika Fakultas Teknik Universitas Muria Kudus. Sistem ini dikembangkan menggunakan ASP dan basisdata MySQL. Metode yang digunakan pada penelitian ini adalah prototyping, dimana aplikasi dikembangkan disesuaikan dengan kebutuhan pengguna (program studi). Hasil penelitian ini adalah prototipe katalog skripsi yang digunakan untuk pengelolaan data-data penjadwalan proposal, seminar dan pelaporan supaya data tersimpan lebih baik di program studi Teknik Informatika.
\end{abstract}

Kata kunci: skripsi, proposal, penjadwalan, web.

\section{ABSTRACT}

Informatics Engineering Department in management thesis on the early department established in 2009 is still done manually. This manual process of managing documents and files completeness thesis recorded and documented using Microsoft Excel file format. Weakness management using document spreatsheet quite a lot, in addition to the document difficult to find whereabouts and documents can be spread across multiple files, in addition to the need for data and complete information related to the results of scheduling exams, supervising theses and seminar results difficult identified and managed properly, if at any time required. In this study, the catalog built on program management thesis in Informatics Engineering Department, Faculty of Engineering, Muria Kudus University. This system was developed using a web-based approach. The method used in this study is prototyping, where applications are developed tailored to the needs of users (courses) related to the functionality of the system developed, ranging from scheduling proposal, seminar and thesis reporting. Results from this study is the prototype information system catalog essay that can be used for data management scheduling proposal, seminars and reporting so that the stored data is better in Informatics Engineering Departmen.

Keywords: thesis, proposals, scheduling, web.

\section{PENDAHULUAN}

Program studi Teknik Informatika adalah program studi baru di Fakultas Teknik Universitas Muria Kudus. Berdiri pada tanggal 4 September tahun 2008 (forlap.dikti.go.id) sebagai awal program studi yang telah meluluskan lebih kurang 250 mahasiswa. Di awal penyelenggaraan kegiatan keakademikan tiap semester program studi Teknik Informatika telah memiliki sistem tersendiri sebagai media komunikasi kepada masyarakat dan seluruh sivitas akdemika, yaitu melalui sistem terintegrasi di Fakultas Teknik.

Program studi teknik informatika saat ini telah memiliki mahasiswa lebih kurang 803 mahasiswa yang aktif (forlap.dikti.go.id). Program studi Teknik Informatika di dalam pengelolaan data-data skripsi dari awal program studi berdiri tahun 2009 sampai dengan sekarang tahun ajaran genap 2014/2015 masih dilakukan secara manual. Proses pengelolaan manual ini memakan waktu yang cukup lama, arsip 
dokumen dan kelengkapan berkas skripsi di catat dan di dokumentasikan dengan menggunakan format file microsoft excel. Kelemahan model pengelolaan menggunakan microsoft excel adalah cukup banyak, selain arsip dokumen sulit di cari keberadaannya, dokumen dapat tersebar di beberapa file-file dikomputer, selain itu kebutuhan data dan informasi yang lengkap terkait hasil pembimbingan proposal skripsi dan laporan ujian skripsi sulit teridentifikasi dan terkelola dengan baik apabila suatu saat dibutuhkan untuk administrasi dosen. Dengan adanya katalog sistem informasi pengelolaan skripsi data akan lebih mudah di kelola dan di dokumentasikan.

Teknologi informasi berkembang sangat cepat khususnya teknologi web. Saat ini telah hadir teknologi web yang dapat digunakan untuk mengembangkan aplikasi dengan mudah yaitu dengan konsep pendekatan .net framework. Teknologi net framework adalah sebuah abstraksi perangkat lunak yang menyediakan fungsi-fungsi generik yang dapat diubah dan dimodifikasi oleh pengguna (programer) dalam rangka mengkonsruksikan aplikasi. Beberapa kelebihan dengan menggunakan .Net framework adalah data/informasi mudah dikontrol sesuai disain awal dan kebutuhan sistem oleh pengguna. Selain itu dengan framework, perangkat lunak mudah dikembangkan (extensibility) ketika fitur aplikasi mengalami perubahan dengan suport banyak bahasa pemrograman [1].

Berdasarkan identifikasi masalah tersebut maka pada penelitian ini perlu dilakukan penelitian dengan judul "Katalog Skripsi Online pada Program Studi Teknik Informatika" untuk menyelesaikan permasalahan yang ada, salah satunya belum tersedianya sistem informasi untuk pengelolaan dan rekapitulasi data-data skripsi pada Program Studi Teknik Informatika.

\section{TINJAUAN PUSTAKA}

Beberapa penelitian terdahulu terkait sistem bimbingan dan skripsi online telah banyak dikembangkan. [2] melakukan penelitian yang menghasilkan aplikasi sistem informasi monitoring tugas akhir berbasis Short Message Services (SMS) di fakultas ilmu komputer Universitas Sriwijaya (Unsri). Pada penelitian tersebut memanfaatkan teknologi SMS untuk membantu monitoring tugas akhir mahasiswa terkait status proposal dan jadwal seminar tugas akhir mahasiswa.

[3] melakukan penelitian yang menghasikan aplikasi untuk bimbingan skripsi online mahasiswa Matematika Fakultas Matematika dan Ilmu Pengetahuan Alam di Universitas Negeri Yogyakarta, yang pada penelitian tersebut lebih menekankan pada proses-proses bimbingan tugas akhir skripsi mahasiswa jurusan pendidikan matematika yang dikembangkan dengan berbasis web.

Ike Verawati., dkk (2014) melakukan penelitian yang menghasilkan analisis kesuksesan sistem bimbingan online STMIK AMIKOM Yogyakarta. Pada penelitian tersebut menganalisa tingkat keberhasilan dari suatu penerapan sistem bimbingan online mulai dari judul hingga proses bimbingan dengan model pengukuran kesuksesan DeLone dan McLean (2003). Aplikasi bimibingan online tersebut dikembangkan dengan web.

[4] melakukan penelitian yang menghasilkan sistem informasi skripsi di Universitas Atma Jaya Yogyakarta. Pada penelitian tersebut telah dihasilkan sistem yang dapat memberikan kemudahan di dalam pengelolaan tugas akhir/ skripsi mahasiswa melalui proses-proses dari mulai pendaftaran, bimbingan sampai dengan ujian.

[5] melakukan penelitian yang menghasilkan sistem bimbingan tugas akhir online pada politeknik muhammadiyah pekalongan. Pada penelitian tersebut memberikan kemudahan bagi mahasiswa dan dosen pembimbing untuk berkomunikasi secara online yang dilengkapi dengan fitur chat.

[6] melakukan penelitian yang menghasilkan sistem informasi tugas akhir online diprogram studi teknik informatika fakultas teknologi informasi dan komunikasi yang memudahkan mahasiswa di dalam pengambilan tugas akhir(TA).

Studi yang dilakukan oleh penulis pada penelitian ini adalah bermaksud untuk merancang dan membangun sistem katalog skripsi di Program Studi Teknik Informatika yang dapat membantu mengelola semua koleksi laporan-laporan skripsi mahasiswa sehingga mudah dicari. Aplikasi yang dibangun berbasis web dan menggunakan bahasa ASP.

\section{METODOLOGI PENELITIAN}

Metodologi penelitian yang digunakan pada penelitian ini adalah model pengembangan perangkat lunak prototyping. Prototyping di disain untuk pengembangan perangkat lunak yang dikerjakan sesuai kebutuhan [7]: 
1) Kebutuhan Spesifikasi

Menentukan spesifikasi sistem katalog skripsi yang akan dibangun. Spesifikasi dapat berupa rancangan menu, user interface dan format laporan-laporan (reporting) pada sistem yang di kehendaki. Kegiatan ini dikonsultasikan kepada Program Studi Teknik Informatika.

2) Verifikasi sistem

Memverifikasi spesifikasi sistem yang telah ditentukan sebelumnya oleh pengguna (operator), apakah fitur telah sesuai dengan spesifikasinya.

3) Validasi sistem

Memvalidasi fitur sistem katalog, seperti input output program supaya berjalan dengan baik sesuai keinginan pengguna.

\section{HASIL DAN PEMBAHASAN}

Pada hasil penelitian ini dijelaskan tahapan-tahapan di dalam membangun prototipe program aplikasi katalog skripsi di Program Studi Teknik Informatika. Tahapan tersebut diantaranya terdiri dari : merancang kebutuhan tabel-tabel progam (tahapan koseptual), membangun skema relasi tabel yang akan digunakan dalam basisdata, menyusun kode program dan pengujian program.

\subsection{Merancang Tabel Program}

Tabel adalah media yang digunakan untuk menyimpan seluruh data-data. Data yang dimaksud disini adalah seluruh koleksi laporan skripsi mahasiswa. Kebutuhan tabel yang digunakan pada penelitian ini terdiri dari : tabel mahasiswa, tabel dosen, tabel mengajar, tabel matakuliah, tabel kartu hasil studi (KHS), tabel kuliah kerja lapangan (KKL), tabel skripsi, tabel proposal, tabel koordinator.

\subsection{Membangun Skema relasi}

Skema menunjukkan struktur rangkaian field-field yang disimpan di dalam tabel-tabel dan berelasi satu sama lain di basisdata. Skema digunakan untuk mendeskripsikan konsep organisasi sistem di basisdata katalog skripsi yang sedang dibangun. Pada Gambar 1. ditunjukkan skema relasi tabel yang telah telah dirancang. Tabel yang diperlukan di dalam penelitian ini adalah tabel dosenajar, tabel dosen, tabel koordinator, tabel mahasiswa, tabel skripsi, tabel khs, dan tabel proposal. 


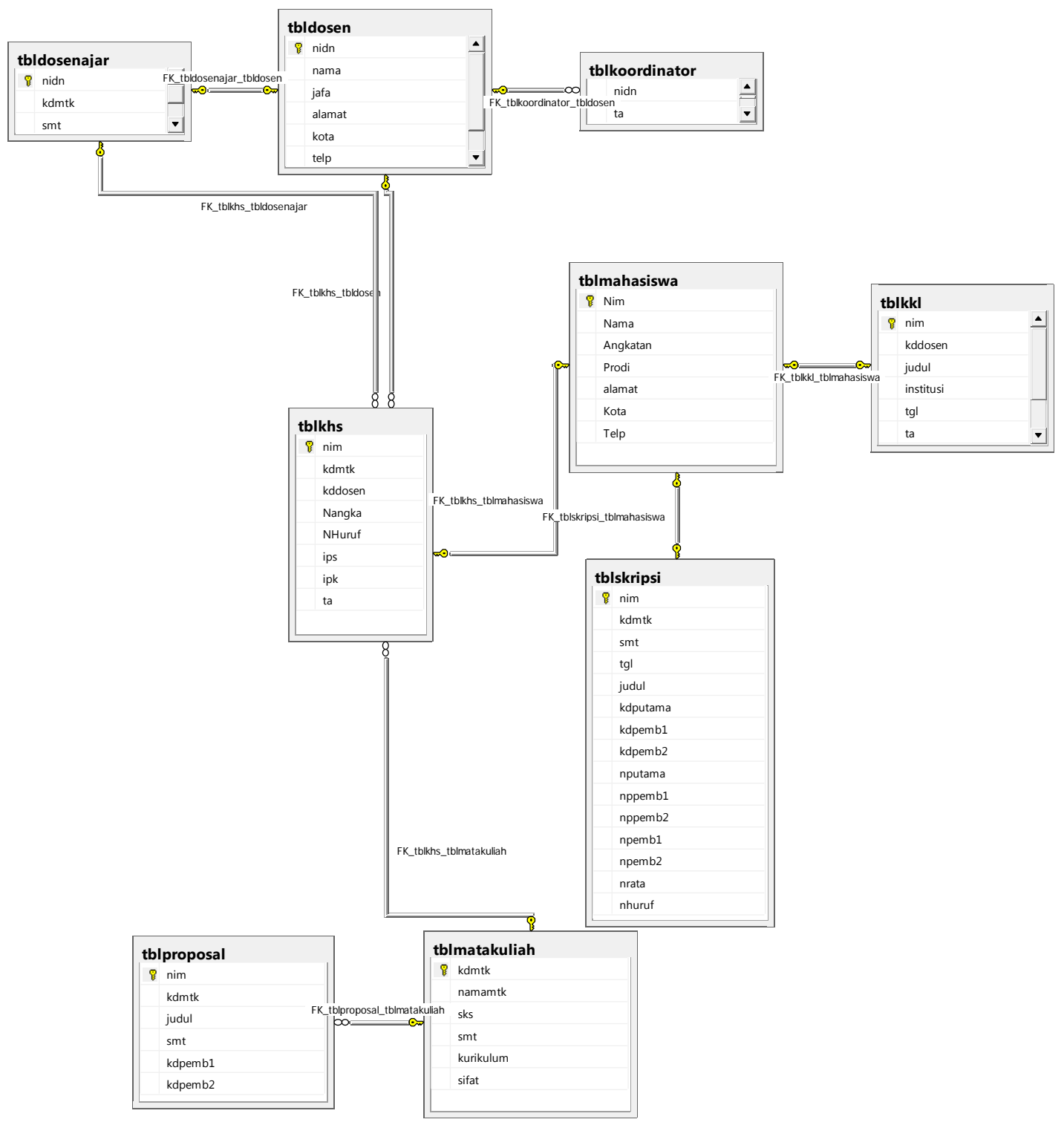

\section{Gambar 1. Skema Relasi Tabel Katalog Skripsi}

\subsection{Menyusun Kode Program}

Kode program adalah sekumpulan instruksi-instruksi yang memiliki tugas-tugas tertentu untuk mengeksekusi program/ sub program. Kode program sering disebut juga sebagai prosedur (procedure) dalam istilah teknik pemrograman. Pada penelitian ini beberapa kode program untuk verifikasi jadwal ujian.

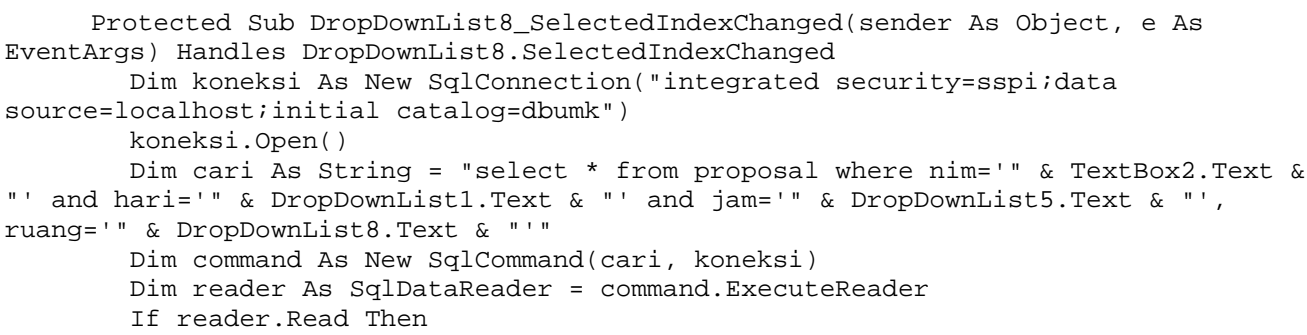


nd Sub

MsgBox("Cek Hari, jam dan ruang", MsgBoxStyle.Information, "Peringatan")

End Class

Kode verifikasi jadwal ujian digunakan untuk memverifikasi jadwal pelaksanaan ujian skripsi supaya tidak bentrok. Kriteria bentrok pada penelitian di dasarkan pada hari, jam dan ruang ujian yang digunakan. Jika terjadi bentrok jadwal maka sistem akan menolak dan mengingatkan kepada user melalui pesan notifikasi untuk memeriksa.

\subsection{Perancangan Antar Muka}

Graphical User Interface atau yang dikenal dengan nama GUI adalah suatu antarmuka perangkat lunak yang digunakan untuk berkomunikasi kepada pengguna terkait penggelolaan data skripsi. Pada disain antarmuka perangkat lunak penelitian ini telah dirancang beberapa form, diantaranya: form dosen, matakuliah, proposal skripsi, skripsi dan laporan informasi tentang skripsi. Pada Gambar 2 menunjukkan form perancangan untuk ujian proposal, yang di dalamnya memuat beberapa data yaitu tahun akademik, NIM, nama mahasiswa, judul proposal ,pembimbing utama dan pembantu dan jadwal skripsi (hari, tanggal dan jam) proposal skripsi disidangkan.

Home Penjadwalan \ Penilaian \ Kurikulum Menampilkan Data cetak Input Data

PENJADWALAN PROPOSAL SKRIPSI

TAHUN AKADEMIK 2016/2017 V SEMESTER GASAL $\checkmark$

NIM

NAMA MAHASISWA

201551001

JUDUL PROPOSAL

PEMBIMBING UTAMA

PEMBIMBING PEMBANTU

Ahmad Rifqi Hidayat

Sistem Informasi Sekolah Berbasis Web Di

Kabupaten Kudus

\begin{tabular}{ll|}
\hline SENIN & $\checkmark$ \\
\hline 1 & $\checkmark$
\end{tabular}

\begin{tabular}{|l|}
\hline MUKHAMAD NURKAMID, M.Cs. \\
\hline AHMAD JAZULI, M.KOM. \\
\hline
\end{tabular}

JAM

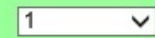

TANGGAL $\quad 05-04-2016$

RUANG J.LTIII.5 $\checkmark$

SIMPAN EDIT BATAL

\section{Gambar 2. Form Input Ujian Proposal}

Pada Gambar 3 adalah disain rancangan antarmuka untuk penjadwalan skripsi yang merupakan aplikasi yang digunakan untuk mengelola jadwal skripsi. Adapun field yang harus diisi adalah tahun akademik, NIM, nama mahasiswa, penguji skripsi (ketua dan anggota penguji), judul skripsi dan jadwal skripsi disidangkan. 


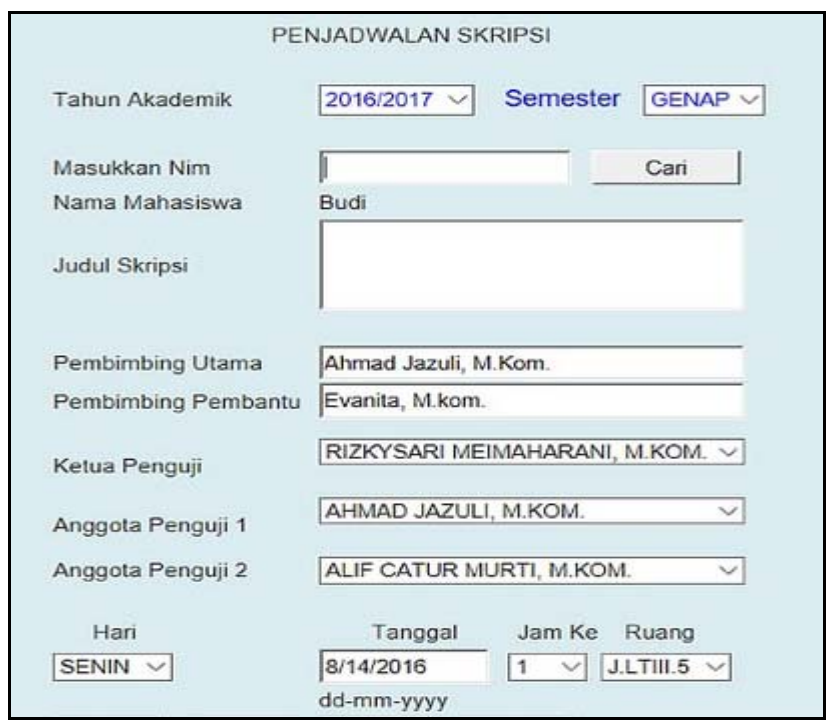

Gambar 3. Form Aplikasi Penjadwalan Skripsi

\subsection{Pengujian Program dengan White Box}

Pengujian program adalah tahapan akhir dari pengembangan perangkat lunak yang sedang dikerjakan dalam penelitian. Pada pengujian sistem prototipe skripsi ini digunakan pendekatan pengujian white box testing. Pengujian white box testing adalah pengujian yang didasarkan pada pengecekan terhadap detail perancangan, menggunakan struktur kontrol dari desain program secara prosecedural untuk membagi pengujian ke dalam beberapa kasus pengujian [8]. Langkah-langkah pengujiannya adalah: (1) mendefinisikan alur logika, (2) membangun kasus untuk digunakan dalam pengujian, (3) melakukan pengujian. Pada Gambar 4 dilakukan pengujian white box untuk validasi tanggal ujian proposal skripsi. Pada kotak / textbox tanggal harus terisi sebelum data disimpan, jika tidak maka aplikasi akan menampilkan pesan penolakan bahwa tanggal ujian belum diinputkan.

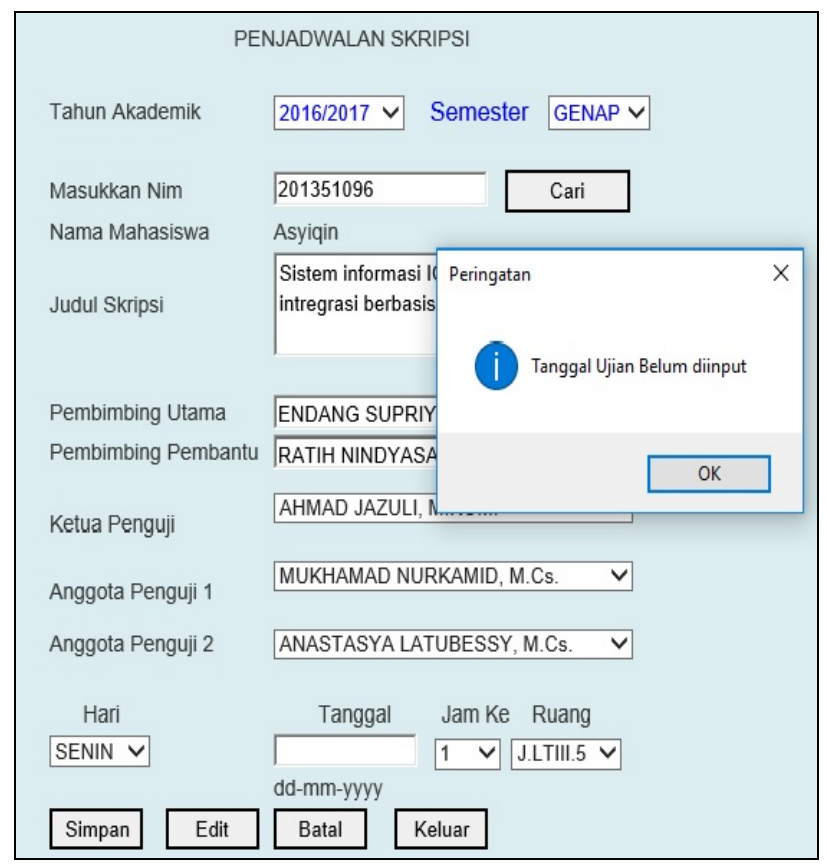

Gambar 4. Pengujian Untuk Validasi Tanggal Ujian

Sedangkan pada Gambar 5 dilakukan pengujian white box untuk validasi jadwal skripsi kepada mahasiswa. Pada textbox 'NIM' pengguna diminta mengisikan sejumlah NIM tertentu mahasiswa, jika 
aplikasi menampilkan judul, pembimbing utama dan pembimbing pembantu artinya mahasiswa tersebut telah mendaftarkan proposal skripsi dan siap di jadwalkan untuk melaksanakan ujian skripsi. Pada sistem jadwal ujian akan ditampilkan, misalnya untuk NIM ' 201351100' dengan nama mahasiswa 'Muchammad Andi Wijayadi', judul proposal skripsi Aplikasi pengidentifikasian peengenalan pola akan ditampilkan lengkap dengan jadwal ujian yaitu pada hari Jumat, tanggal 15 Oktober 2015 jam ke I Ruang J.Lt.III.5.

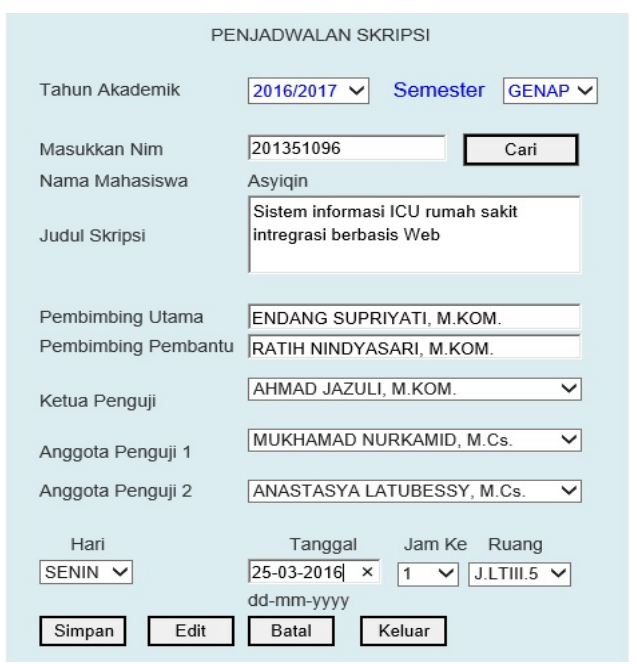

Gambar 5. Pengujian Validasi Mahasiswa Sudah Ujian Skripsi

Pada Gambar 6 dilakukan pengujian white box untuk validasi judul skripsi mahasiswa. Pada textbox 'Masukan Judul Yang akan di cari' pengguna diminta mengisikan judul skripsi, misal ,'sistem pendukung keputusan'. Jika sesuai maka hasil skripsi mahasiswa dengan judul sistem pendukung keputusan akan di tampilkan beserta jumlah banyaknya judul.

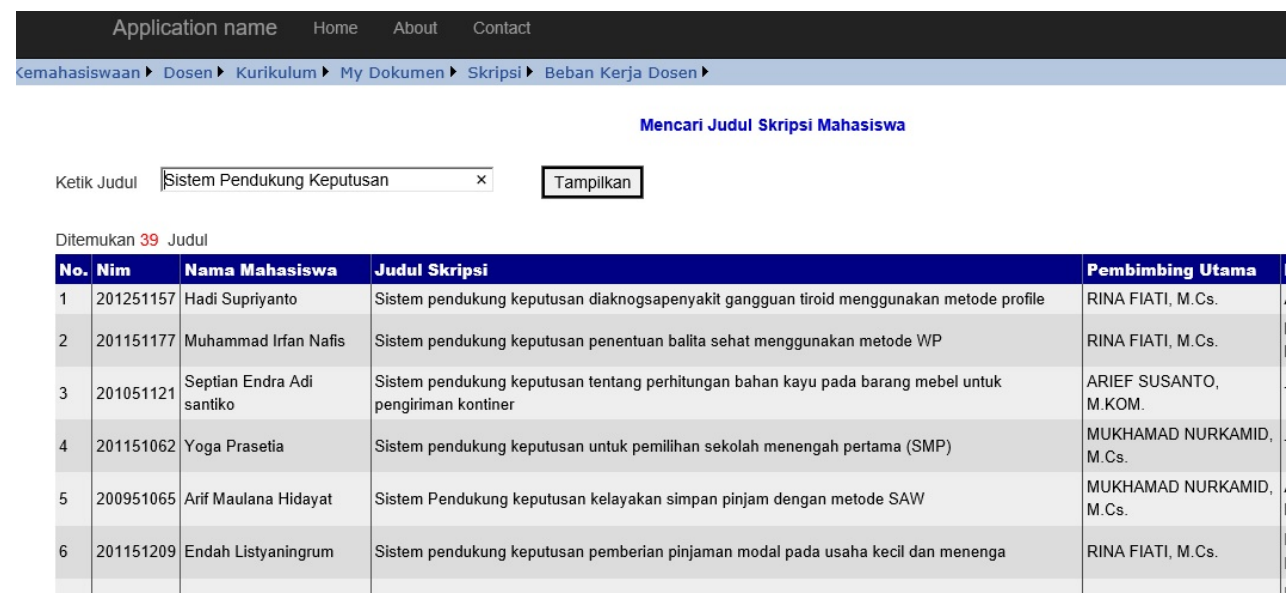

Gambar 6. Pengujian Validasi Judul Skripsi

\section{KESIMPULAN DAN SARAN}

Hasil pada penelitian ini adalah aplikasi untuk pengelolaan skripsi, mulai dari penjadwalan proposal, seminar hasil dan laporan pelaksanaan ujian skripsi yang dapat digunakan untuk membantu tugas-tugas program studi mengelola data-data skripsi.

Saran pada penelitian ini sistem yang dibangun berbasis web sehingga pengembangan kedepan dapat diperluas menggunakan platform mobile/ android sehingga bisa diakses dengan smartphone. 


\section{DAFTAR PUSTAKA}

[1] Riehle, D. 2000. Framework Design: A Role Modeling Approach. Ph.D. Thesis, No. 13509. Zürich, Switzerland, ETH Zurich. (Online), (http://dirkriehle.com/computerscience/research/dissertation/index.html, diakses 5 November 2016).

[2] Ibrahim, A. 2011. Pengembangan Sistem Informasi Monitoring Tugas Akhir berbasis Short Messages Services (SMS) Gateway di Fasilkom Unsri. Jurnal Sistem Informasi Indonesia (JUSI), Universitas Ahmad Dahlan, Yogyakarta. (Online), (http://is.uad.ac.id/jusi/files/08-JUSI-Vol-1-No-2-_Pengembangan-SistemInformasi-Monitoring-TA-Berbasis-SMS-di-Fasilkom-Unsri.pdf, diakses 30 Desember 2016).

[3] Jaka, P, M. 2014. Aplikasi Bimbingan Skripsi Online Mahasiswa Jurusan Pendidikan Matematika Fakultas Matematika dan Ilmu Pengetahuan Alam. Universitas Negeri Yogyakarta, Laporan Skripsi Sarjana, Yogyakarta. (Online), (http://eprints.uny.ac.id/12686/1/Muhammad\%20Jaka\%20P.pdf, diakses 6 Desember 2016).

[4] Alisius Dikcky Hutama, P. 2014. Pembangunan Sistem Informasi Skripsi dan Tugas Akhir pada Universitas Atma Jaya Yogyakarta. Laporan Skripsi Sarjana, UAJY, Yogyakarta. (Online), (http://ejournal.uajy.ac.id/6341/, diakses pada tanggal 30 Desember 2016).

[5] Mutaalimah, R dan Rosyadi, I. 2015. Sistem Informasi Bimbingan Tugas Akhir Online pada Politeknik Muhammadiyah Pekalongan. Jurnal Teknik Informatika Surya Informatika, Vol.I, No. 1 November 2015. (Online), http://ejournal.politeknikmuhpkl.ac.id/index.php/3/article/view/5/35, diakses 14 Desember 2016)

[6] Nugroho, A., Wakhidah, N., Christioko., V., B. 2015. Sistem Informasi secara Online Tugas Akhir mahasiswa Jurusan Teknologi Informasi Fakultas Teknologi Informasi dan Komunikasi Universitas Semarang, Jurnal Transformatika, Vol.13, No.1, Juli 2015. Semarang. (Online), (http://journals.usm.ac.id/index.php/transformatika/article/view/104)

[7] Sommerville, I, 2000. Software Engineering: Software Prototyping Chapter, 10th Edition. (Online), ( http://iansommerville.com/software-engineering-book/slides/, diakses 28 November 2016).

[8] Pressman, R.2010. Software Engineering : A practitioner Approach. Seven Edition. Mc-Graw Hill, New York, USA.

[9] Rony, A., M., Putra, S., U., P., Kalvinly, Asmarani, D., B., 2012. Sistem Informasi Dosen Penasehat Akademik pada Fakultas Teknologi Informasi Universitas Budi Luhur. Prosiding Seminar Nasional Teknologi Informasi \& Komunikasi Terapan 2012 (Semantik 2012), Vol.2., No.1., ISBN: 979-260255-0, hal.42-46, Fakultas Ilmu Komputer-Universitas Dian Nuswantoro Semarang, Semarang. (Online), (http://publikasi.dinus.ac.id/index.php/semantik/article/view/67, diakses 24 November 2016).

[10] Verawati, I., Winarno, W, W., Sunyoto, A. 2014. Analisis Kesuksesan Sistem Bimbingan Online STMIK AMIKOM Yogyakarta, Seminar Nasional Informatika 2014. STMIK Amikom, Yogyakarta. (Online),(http://riset.potensi utama.ac.id/upload/penelitian/penerbitan_jurnal/6065 analisis_kesuksesan_sistem_bimbingan_online_stmik_amikom_yogyakarta.pdf, diakses 10 Desember 2016). 